\title{
Factors influencing the magnitude, duration, and rate of fall of $B$-cell function in Type 1 (insulin-dependent) diabetic children followed for two years from their clinical diagnosis
}

\author{
M. Wallensteen ${ }^{1}$, G. Dahlquist ${ }^{2}$, B. Persson ${ }^{1}$, M.Landin-Olsson ${ }^{4}$, A. Lernmark ${ }^{4}$, G. Sundkvist ${ }^{4}$ and B. Thalme $^{3}$ \\ Departments of Paediatrics, Karolinska Institute, ' St. Göran's children's Hospital, ${ }^{2}$ Sachs' Children's Hospital, and \\ ${ }^{3}$ Huddinge Hospital, Stockholm, Sweden, and \\ ${ }^{4}$ Department of Internal Medicine, University of Lund, Malmö General Hospital Malmö, Sweden
}

\begin{abstract}
Summary. The pattern of fall in B-cell function measured as plasma and $24 \mathrm{~h}$ urinary C-peptide excretion, as well as levels of islet cell antibodies, insulin antibodies and metabolic parameters, were followed for two years in 39 children aged 1-17 years prospectively from clinical onset of Type 1 (insulin-dependent) diabetes. At onset $32 / 36$ patients had measurable plasma C-peptide (median $0.13 \mathrm{nmol} / \mathrm{l}$ ). Maximum values of fasting and postprandial plasma $\mathrm{C}$ peptide were reached at a median duration of three months. Thereafter both plasma and urinary C-peptide declined linearly. The median value of the rate of fall in postprandial plasma C-peptide was $0.019 \mathrm{nmol} \cdot 1^{-1} \cdot$ month $^{-1}$. Age at onset was positively correlated to the maximum value of postprandial plasma C-peptide in each patient $\left(\mathrm{r}_{\mathrm{s}}=0.57\right.$, $p=0.0001$ ) and throughout the observation time positively correlated to fasting and postprandial $\mathrm{C}$-peptide and to the $24 \mathrm{~h}$ urinary $\mathrm{C}$-peptide excretion $\left(\mathrm{r}_{\mathrm{s}}\right.$ range $0.35-0.70$, $p=0.03-0.0001$ ). The rate of fall of postprandial C-peptide
\end{abstract}

was unrelated to age at onset and was strikingly parallel in different age groups. Islet cell antibodies were present in $87 \%$ of the patients at onset and decreased to $38 \%$ at 24 months. Islet cell antibody titres were not correlated to age at onset or to plasma or urinary C-peptide at any single observation. However, islet cell antibody negative patients had significantly higher $(p<0.05)$ postprandial plasma Cpeptide values at 1,9 , and 12 months of duration, compared to islet cell antibody positive patients. Insulin antibodies and metabolic state at onset did not influence the C-peptide values. It is concluded that age at onset is the most important variable in predicting the duration and magnitude of endogenous insulin secretion during the first two years of Type 1 diabetes in children.

Key words: Children, Type 1 (insulin-dependent) diabetes, Cpeptide, islet cell antibodies, insulin antibodies.
At the time of clinical diagnosis of Type 1 (insulin-dependent) diabetes mellitus in children, diagnosis indicates that a considerable amount of pancreatic B cells have been destroyed $[1,2]$. Studies of B-cell function, measured as C-peptide in plasma in Type 1 diabetic children have shown an increase in plasma C-peptide levels shortly after the initiation of insulin therapy, suggesting that the function of the remaining $B$ cells is, at least temporarily, restored [3, 4]. Normalisation of the metabolic state also increases the peripheral insulin sensitivity $[5,6]$. The overall results are reduced external insulin requirement, allowing the patients to enter a phase of clinical partial remission, but the destruction of the remaining B cells continues progressively; and a few years after onset most children with Type 1 diabetes are deficient in, or have low endogenous, insulin secretion. Cross-sectional studies have shown a positive correlation between age at onset and the duration of the remission period and also between age at onset and the level of plasma C-peptide [7-8]. The $24 \mathrm{~h}$ urinary C-peptide excretion in relation to the
$24 \mathrm{~h}$ urinary creatinine excretion was positively correlated to age at onset in a small prospective study [9] but in a cross-sectional study comprising a large number of children this relation was not found [10].

At the clinical onset of diabetes, islet cell antibodies (ICA) [11], islet cell surface antibodies (ICSA) [12], as well as insulin antibodies (IAB) [13] have been detected, suggesting that immunological mechanisms take part in the pathogenetic process of Type 1 diabetes. In a study of children and adults with Type 1 diabetes persistence of ICA throughout a 30 month period was found to be associated with an increased rate of fall in fasting C-peptide levels [14]. In another study, however, comprising only diabetic children, patients with persistent levels of complement-fixing ICA (CF-ICA) had higher levels of postprandial serum Cpeptide during the second year of diabetes compared to those who became negative for CF-ICA during the observation period [4]. The presence of high levels of insulin antibodies in children with Type 1 diabetes have been suggested to be associated with a shorter re- 
Table 1. Fasting blood glucose, $\mathrm{HbA}_{1 \mathrm{c}}$ (normal range 6-8\%), insulin antibodies and insulin dose during the first two years of diabetes in 39 children. Values are given as median and interquartile range (in paranthesis)

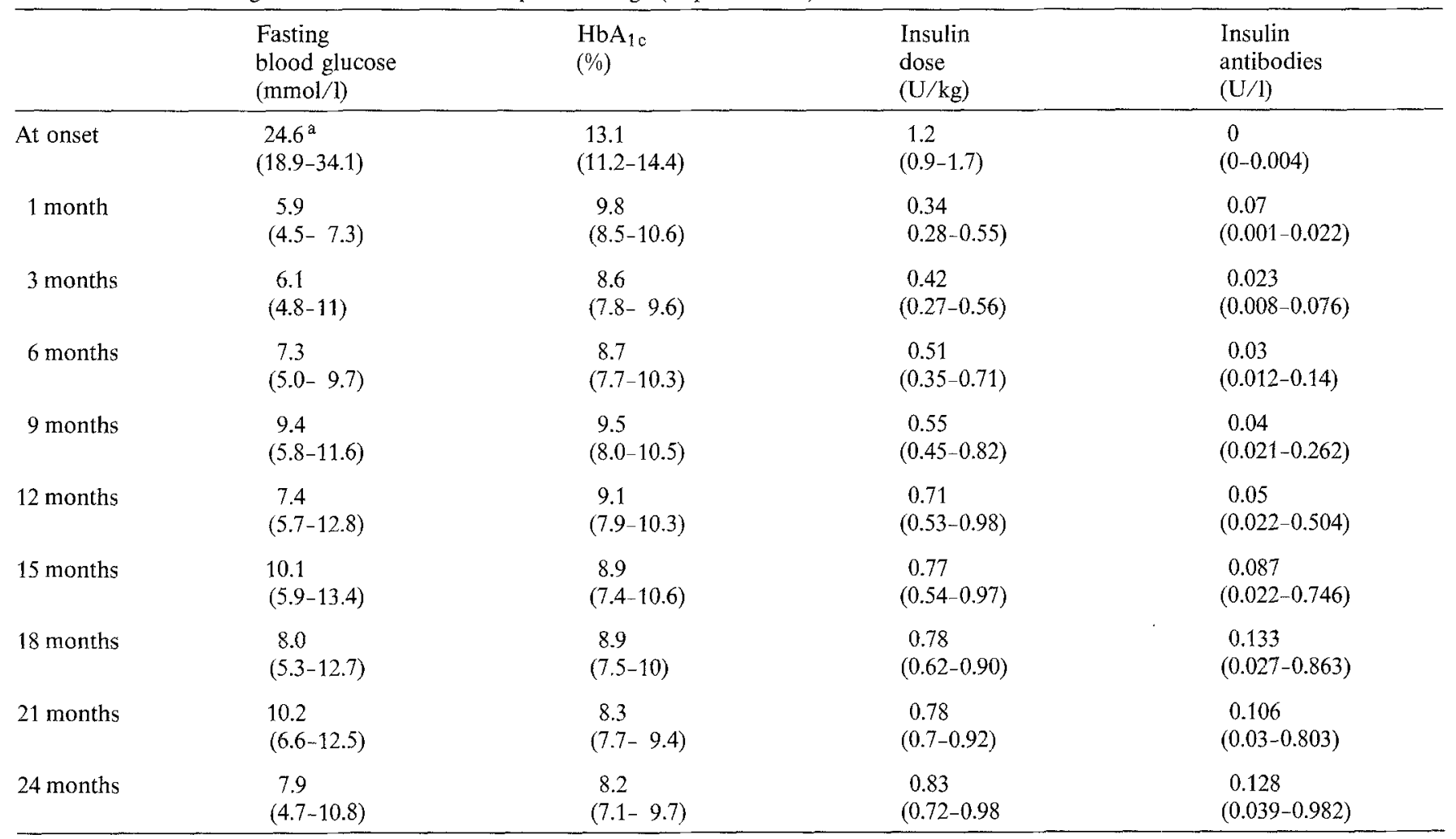

${ }^{\text {a }}$ Blood glucose at clinical diagnosis

mission period [15] while others have found the presence of these antibodies to be related rather to age at onset of diabetes [16-17].

In the present study, the pattern of change in endogenous insulin secretion in 39 children was prospectively followed for two years from clinical onset of diabetes. The aim was to study the influence of: age at onset, metabolic state at onset, and immunological parameters such as the levels of ICA and IAB on the duration, the magnitude, and the individual rate of fall in B-cell function measured as C-peptide in plasma and in urine.

\section{Subjects and methods}

Informed consent was obtained from all children and their parents and the study was approved by the local Ethical Committee. A total of 39 consecutive patients ( 16 girls and 23 boys), from three paediatric departments in Stockholm took part in the study, which was conducted between 1982 and 1985. Another six patients did not participate or dropped out during the follow up, for various reasons. The mean and median age was 9 years with a range of 1-17 years. At the time of diagnosis before the initiation of insulin therapy samples, were taken for analysis of plasma C-peptide, blood glucose, urinary glucose, IAB, and ICA. Metabolic state at onset was evaluated by blood analysis of base deficit, 3-hydroxybutyrate, and $\mathrm{HbA}_{10}$. After one month, after three months and every three months thereafter during two years the following parameters were analysed: fasting plasma C-peptide before morning insulin injection $\left(\mathrm{PCP}_{0}\right)$, plasma $\mathrm{C}$-peptide $90 \mathrm{~min}$ after a standardised breakfast $\left(\mathrm{PCP}_{90}\right.$ ), the $24 \mathrm{~h}$ urinary $\mathrm{C}$-peptide excretion collected the previous day and night, blood glucose, the $24 \mathrm{~h}$ urinary glucose excretion, insulin antibodies (IAB), and $\mathrm{HbA}_{1 \mathrm{c}}$. The urinary collection was carried out at home after thorough instructions. An aliquot of $10 \mathrm{ml}$ was withdrawn from the collection, $\mathrm{pH}$ adjusted to $>7$ and kept at $-20^{\circ} \mathrm{C}$ until assay, which was performed within three weeks to avoid degradation. The accuracy of the urinary collection was assessed by determining the $24 \mathrm{~h}$ urinary creatinine excretion [18]. The rate of fall of postprandial plasma C-peptide was calculated ind:vidually as the regression line drawn from the maximum value in each individual. The rate of increase of IAB was calculated in the same manner. The value of the regression coefficient was regarded as the rate of fall or the rate of increase. ICA were analysed at onset, at 1, 3, $6,12,18$, and 24 months.

The children were treated with 2 or 3 daily doses of short- and/or intermediate-acting highly purified monocomponent pork or semisynthetic human insulin. There were no significant differences in any of the parameters tested, including insulin antibodies, between patients treated with pork or human insulin. All subjects regularly attended the outpatient clinic at one of the three paediatric departments, who followed a similar treatment program according to the outlines in the Swedish Health Care Program for children with Type 1 diabetes.

\section{Chemical methods}

C-peptide was analysed according to the method of Heding, using the M1230 antibody [19]. The intra- and interassay coefficients of variation for plasma were $2.6 \%$ and $7.2 \%$ and for urine $2.4 \%$ and $7.0 \%$ respectively. The lower detection limit in this assay for plasma and urine is $0.05 \mathrm{nmol} / 1$. Before assay the plasma samples were treated with polyethylene glycol. The urine samples were diluted 1:20 with phosphate buffer before analysis. $\mathrm{HbA}_{1 \mathrm{c}}$ was measured using an isoelectric focusing technique, reference value 6-8\% [20]. Plasma 3-hydroxybutyrate was determined by an enzymatic fluorometric method [21]. Urinary creatinine was analysed using a Beckman creatinine analyser II (Beckman Instrument Inc., Fuller- 


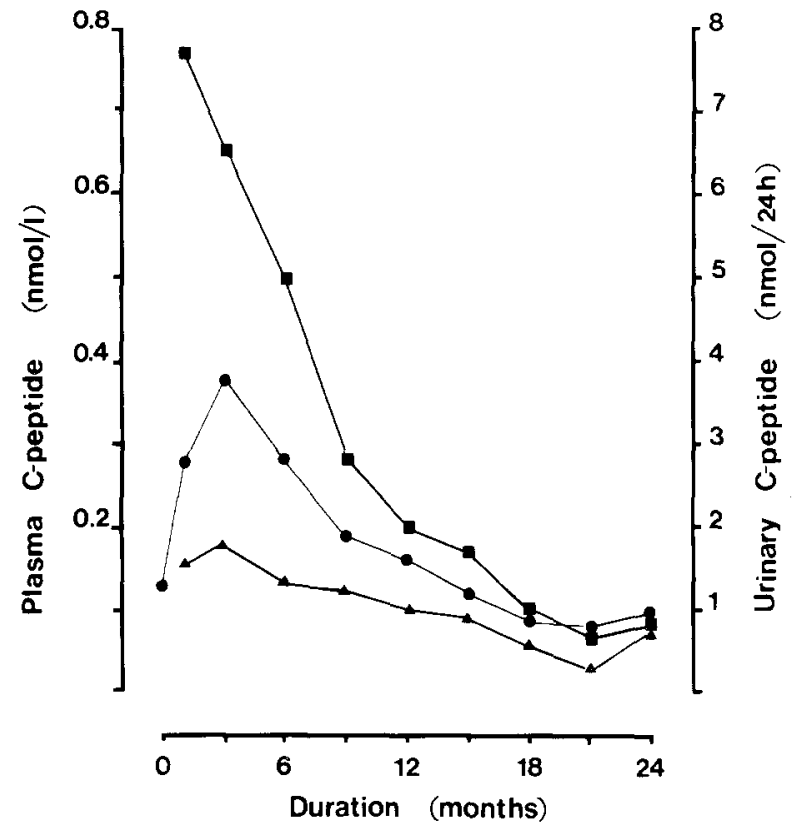

Fig. 1. Median values of fasting plasma C-peptide (A), postprandial plasma C-peptide (O), and the $24 \mathrm{~h}$ urinary C-peptide ( $\mathbf{(})$ in relation to duration of diabetes

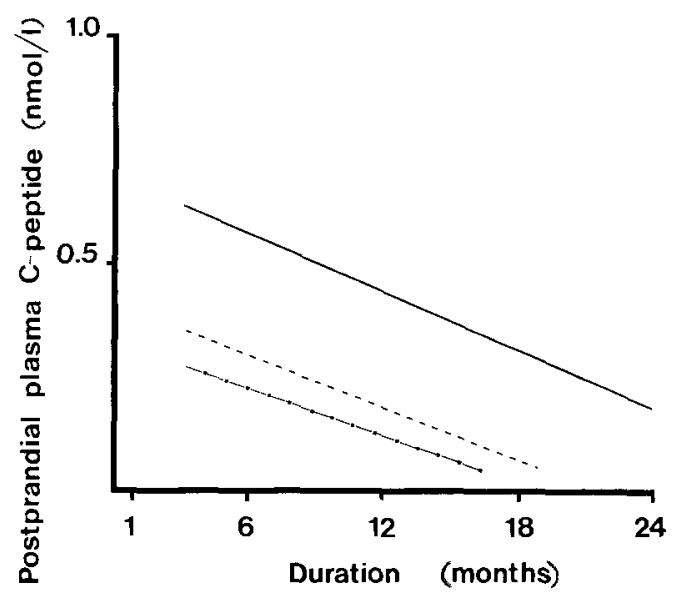

Fig. 2. Rate of fall of postprandial plasma C-peptide in different age groups. The equations of the regressions are: $1-5$ years $(\mathbf{D}), n=7$, $\mathrm{y}=-0.017 \times+0.33) ; 6-11$ years $(----), n=22, \mathrm{y}=-0.019 \times+0.42$; and $12-17$ years $(-), n=10, \mathrm{y}=-0.021 \times+0.70$. The extrapolated y intercepts are significantly different, $p<0.005$

ton, Calif., USA). Base deficit, blood glucose, and urinary glucose were analysed at the hospital laboratories using conventional methods. ICA were analysed using a two-colour immunofluorescence test with prolonged incubation. The interassay coefficient of variation for the method is 0.92 titration steps [22]. The titres of ICA are expressed as Juvenile Diabetes Foundation (JDF) units by comparing to an international reference serum [23]. IAB were analysed according to the method of Christiansen [24]. Bovine ${ }^{125}$ I insulin was used as a tracer and the upper limit for normal seras were $0.012 \mathrm{U} / 1$.

\section{Statistical analysis}

Because of non-normal distributions, non-parametric methods were used for the calculation of correlations using the Spearman's rank correlation test. To estimate differences between groups the Mann-
Whitney U test was used. When comparing more than two groups the Kruskall-Wallis one-way analysis of variance was used. A $p$ value of 0.05 or less was considered significant.

\section{Results}

\section{Pattern of fall in B-cell function}

Fasting blood glucose, $\mathrm{HbA}_{1 \mathrm{c}}, \mathrm{IAB}$, and insulin dose at clinical diagnosis and at $1,3,6,9,12,15,18,21$, and 24 months are shown in Table 1. Fasting plasma Cpeptide $\left(\mathrm{PCP}_{0}\right.$ and stimulated $\mathrm{C}$-peptide $\left(\mathrm{PCP}_{90}\right)$ were significantly correlated at each test point $\left(\mathrm{r}_{\mathrm{s}}\right.$ range $0.72-0.90 ; p=0.0001$ ). There was a significant correlation between the $24 \mathrm{~h}$ urinary C-peptide (UCP) and plasma C-peptide from 3 to 24 months of duration $\left(\mathrm{PCP}_{0}\right.$ versus $\mathrm{UCP} \mathrm{r}_{\mathrm{s}}$ range $0.67-0.81 ; p<0.001$ and $\mathrm{PCP}_{90}$ versus UCP $\mathrm{r}_{\mathrm{s}}$ range $0.59-0.86, p=0.02 \quad-$ $<0.001)$. At one month of duration, however, there was no significant correlation between plasma $\left(\mathrm{PCP}_{0}\right.$ and $\left.\mathrm{PCP}_{90}\right)$ and urinary $\mathrm{C}$-peptide measurements. At the time of clinical diagnosis 32 out of 36 patients had measurable plasma C-peptide (median $0.13 \mathrm{nmol}$, interquartile range $0.08-0.26 \mathrm{nmol} / \mathrm{l})$. Thereafter, there was an increase in C-peptide levels. The maximum value of postprandial C-peptide (median $0.48 \mathrm{nmol} / 1$, interquartile range $0.31-0.67 \mathrm{nmol} / \mathrm{l}$ ) was measured in most patients at 1-6 months after diagnosis with a median of 3 months. Thereafter, there was a linear decline in C-peptide levels. The relationship between the median values of fasting $\mathrm{C}$-peptide, postprandial plasma C-peptide, and the $24 \mathrm{~h}$ urinary C-peptide excretion in relation to duration is illustrated in Figure 1. The median value of the rate of fall of postprandial plasma C-peptide was $0.019 \mathrm{nmol} \cdot 1^{-1} \cdot$ month $^{-1}$ (interquartile range $0.015-0.024 \mathrm{nmol} \cdot 1^{-1} \cdot$ month $^{-1}$ ).

At 24 months the fasting and postprandial plasma $\mathrm{C}$-peptide and the $24 \mathrm{~h}$ urinary C-peptide were inversely correlated to insulin dose ( $r_{\mathrm{s}}$ range -0.44 to $-0.49 ; \quad p<0.01)$, and to fasting blood glucose $\left(r_{s}=\right.$ -0.39 to $-0.44, p<0.05)$. $\mathrm{HbA}_{1 \mathrm{c}}$ was inversely correlated to fasting and postprandial plasma $\mathrm{C}$-peptide $\left(\mathrm{r}_{\mathrm{s}}=-0.33, p=0.04\right.$ and $\left.\mathrm{r}_{\mathrm{s}}=-0.35, p=0.03\right)$ but not to the $24 \mathrm{~h}$ urinary $\mathrm{C}$-peptide excretion.

Age in relation to the magnitude, the duration, and the rate of fall in B-cell function

Age was positively correlated to the individual maximum value of postprandial plasma C-peptide $\left(\mathrm{r}_{\mathrm{s}}=0.57, p=0.0001\right)$ as well as to fasting, postprandial, and to the $24 \mathrm{~h}$ urinary C-peptide at $1-24$ months $\left(\mathrm{r}_{\mathrm{s}}\right.$ range $\left.0.35-0.7, p=0.03-0.0001\right)$. When the $24 \mathrm{~h}$ urinary C-peptide excretion was expressed per $\mathrm{kg}$ body weight a positive correlation to age at onset was found only at 18 months $\left(r_{s}=0.39, p=0.02\right)$. The rate of fall 


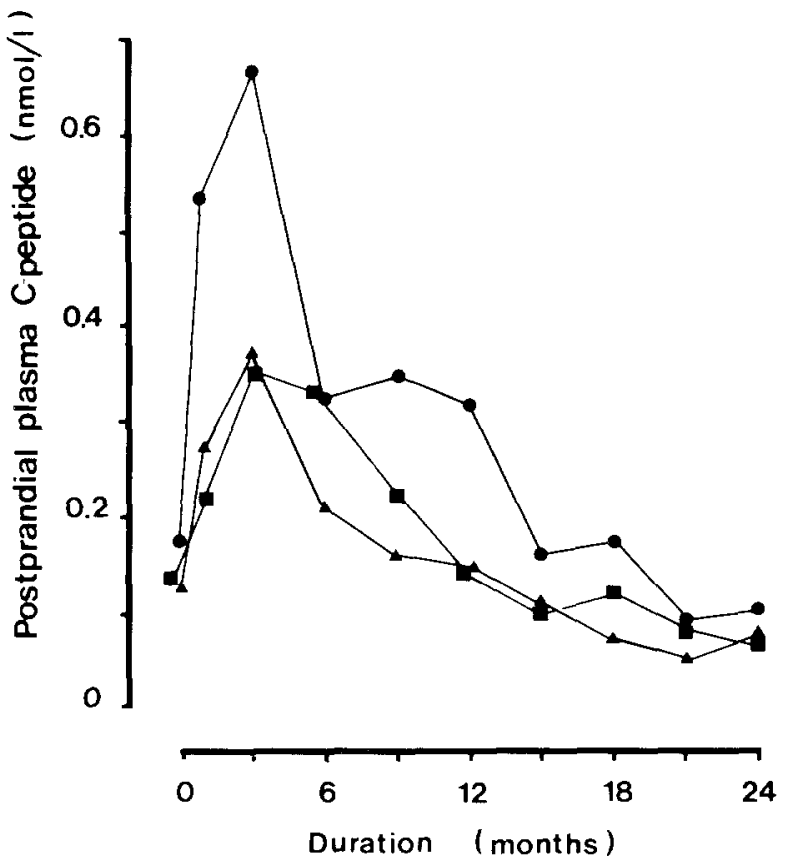

Fig. 3. Median values of postprandial plasma C-peptide in relation to duration of diabetes for patients with islet cell antibodies (ICA) titres $<10$ JDF units $(\mathbf{O}), n=7$; patients with persistent ICA titres $(\mathbf{A})$, $n=12$; and patients who were ICA positive at onset and became negative during follow-up $(\boldsymbol{\square}), n=18$. There was a significant difference between patients with ICA $<10 \mathrm{JDF}$ units and patients with ICA $\geq 10$ JDF units at $1(p=0.05)$, at $9(p=0.01)$, and at $12(p<0.03)$ months

of postprandial plasma C-peptide was, however, not correlated to age at onset. As shown in Figure 2, the rate of fall was similar in different age groups. The extrapolated $y$-intercepts in the different age groups were significantly different, $p<0.005$.

\section{Metabolic state at clinical diagnosis in relation to the magnitude, the duration, and the rate of fall of $B$-cell function.}

Indices of metabolic state at onset were not correlated to measures of residual B-cell function. Neither were there any correlations between the rate of fall of postprandial plasma $\mathrm{C}$-peptide and indices of metabolic control.

\section{$I C A$ and IAB in relation to the magnitude, the} duration and the rate of fall of $B$-cell function

ICA were present in $34 / 39(87 \%)$ patients at diagnosis (median 42 , range $4-1100 \mathrm{JDF}$ units), in $27 / 38(71 \%)$ at 12 months (median 42, range 3-1100 JDF units), and in $14 / 37(38 \%)$ patients after 24 months (median 26, range 3-430 JDF units). Three patients were persistently ICA negative and another four had ICA titres which remained below $10 \mathrm{JDF}$ units. At onset 18 patients were ICA positive but became negative or had a titre below 10 JDF units at the end of the observation period and 12 patients were persistently ICA positive. There were no significant differences in age distribution between these three groups of patients.

At each time of duration studied, postprandial plasma C-peptide values as well as the rate of fall were not correlated to ICA titres $\left(r_{s}=0.03-0.19\right)$.

Patients with ICA titres < 10 JDF units had significantly higher postprandial plasma $C$-peptide at 1 $(p=0.05), 9(p=0.01)$, and $12(p=0.03)$ months of duration compared to patients with ICA $\geq 10$ (Fig.3). The median values of the individual rates of fall in these groups were not significantly different (0.019-0.020 nmol $\cdot 1^{-1} \cdot$ month $\left.^{-1}\right)$. There was no difference in the level of postprandial plasma C-peptide between persistently ICA positive patients and patients who became ICA negative during the observation period (Fig. 3). No correlations were found between ICA at onset, ICA at 24 months, or ICA maximum in each patient on one hand and postprandial plasma C-peptide at 24 months, the peak value of postprandial C-peptide, or the rate of fall on the other hand.

Before insulin therapy, 14/39 patients had measurable levels of IAB in plasma (range $0.001-0.023 \mathrm{U} / 1$ ). At 24 months, $37 / 38$ patients had IAB (median $0.128 \mathrm{U} / 1$, interquartile range $0.039-0.982 \mathrm{U} / 1)$. The median of the individual rate of increase of $I A B$ was $0.006 \mathrm{U} \cdot 1^{-1} \cdot$ month $^{-1}$, interquartile range 0.003 $0.046 \mathrm{U} \cdot 1^{-1} \cdot$ month $^{-1}$. There was no significant correlation between the rate of fall of postprandial plasma C-peptide and the rate of increase of IAB. Postprandial plasma C-peptide was significantly correlated to IAB only at 24 months. There was nc correlation between insulin dose and IAB level.

\section{Discussion}

Among all factors examined in this study, age was found to be the most important and single variable to predict the magnitude and duration of endogenous insulin secretion. This is in agreement with Sochett et al. [25], who followed children with diabetes prospectively for one year from diagnosis. In the present study the rate of fall in B-cell function was strikingly parallel in different age groups and independent of age and metabolic parameters at onset. The observed difference in the level of postprandial plasma C-peptide between the different age groups at onset of diabetes is in agreement with the finding of a positive relationship between age and C-peptide in both plasma and urine in normal children $[18,26]$. Thus, at the time of diagnosis older children have higher C-peptide levels as compared to younger children. This age dependent difference in plasma C-peptide levels and hence insulin secretion, could also reflect differences in insulin sensitivity between young children and adolescents. 
This view is supported by recent observations of a relative insulin resistance in adolescents with and without diabetes $[27,28]$. Thus, one could hypothesize that clinical signs of diabetes may appear at an earlier phase of the B-cell destructive process during puberty and thus lead to a longer period of residual insulin secretion.

The individual rate of fall of postprandial plasma C-peptide was unrelated to levels of ICA and IAB. However, patients with very low or negative levels of ICA seem to have better B-cell function, as a group, during the first year of disease, compared to patients who were ICA positive. This observation is partly in agreement with that reported by Marner et al. [14] who studied a larger group of patients but with a wider age range (0-69 years). In disagreement with our findings, these authors showed that persistently ICA positive patients as a group had an increased rate of fall in median fasting plasma C-peptide values compared to the ICA negative patients. It is likely that this seemingly contradictory finding can be attributed to the marked difference in age distribution between these two studies. The diabetes control and complications trial (DCCT) research group [29] also found that endogenous insulin secretion continues for a longer period of time in adults compared to adolescents with Type 1 diabetes. Mustonen et al. [4] who studied a group of patients well comparable to ours with regard to age and sex, found that patients who were persistently positive for complement-fixing ICA (CF-ICA) had higher postprandial plasma C-peptide during the second year after onset of diabetes, compared to children who became CF-ICA negative. Complement fixing ICA, which have been proposed to occur only in patients with very high levels of ICA [30], were not analysed in the present study. However, the pattern of change in postprandial C-peptide in relation to IgGICA is essentially the same in the two studies, though we did not find any difference between persistently ICA positive patients and those who became negative.

The IAB levels were low, but 14 out of 39 children had measurable IAB even before the start of insulin treatment, which is in accordance with previous reports $[13,15]$. Neither the presence of IAB at the time of clinical onset nor the subsequent formation of IAB following insulin therapy were correlated to fasting or postprandial C-peptide during the first 18 months. However, at 24 months there was an inverse correlation between IAB levels and postprandial C-peptide. The pathophysiological role of IAB is unclear. The inverse relationship between $\mathrm{IAB}$ and $\mathrm{C}$-peptide at 24 months of duration only could be confounded by the relationship between IAB and age or, could be explained by the possibility that the formation of IAB during insulin therapy is detected only when analysed prospectively. The rate of fall in postprandial plasma C-peptide was, however, not correlated to the rate of increase of IAB. Fasting and postprandial plasma C- peptide were closely related throughout the study. The present finding of a successively diminished postprandial plasma C-peptide response may be attributed to the ongoing destruction of the pancreatic B cells but also partly to the ensuing hyperglycaemia, which has been shown to influence B-cell function [31]. A close relationship between measures of plasma and urinary C-peptide was also found from three months of duration. The lack of such relationship in the early phase of the disease could suggest a different turnover of $\mathrm{C}$ peptide during this period. This could be a concequence of an altered renal elimination of C-peptide $[32,33]$.

In conclusion, our study has shown that the magnitude and duration of residual B-cell function in Type 1 diabetes in children is dependent on the age at onset whereas the rate of fall of postprandial plasma C-peptide is very similar, parallel and unrelated to age. Although patients with very low titres of ICA seemed to have higher $\mathrm{C}$-peptide levels during the first year of diabetes, the lack of correlation between C-peptide and ICA levels at each time of observation during the two year study period indicates that ICA are of limited value to predict the duration of endogenous insulin secretion in the individual patient.

Acknowledgements. This study was supported by grants from the Karolinska Institute, Svenska Diabetesstiftelsen, Tielman's Fund for Paediatric Research, and the Swedish Medical Research Council (grant nos.7507, 7531). We wish to thank the NOVO Research Laboratories for analysis of IAB and Ms. G.-M. Taube and Ms. C. Johansson for expert technical assistance.

\section{References}

1. Gepts W, de Mey J (1978) Islet cell survival determined by morphology. An immunocytochemical study of the Islets of Langerhans in juvenile diabetes mellitus. Diabetes [Suppl.] 27: 251-261

2. Foulis A, Stewart J (1984) The pancreas in recent onset Type 1 (insulin-dependent) diabetes mellitus: insulin content of islets, insulitis and other associated changes in the exocrine acinar tissue. Diabetologia 26: 456-461

3. Ludvigsson J, Heding L (1978) Beta-cell function in children with diabetes. Diabetes [Suppl.] 27: 230-234

4. Mustonen A, Knip M, Huttunen N-P, Puukka R, Käär M-L, Åkerblom H (1984) Evidence of delayed B-cell destruction in Type 1 (insulin-dependent) diabetic patients with persisting complement-fixing cytoplasmic islet cell antibodies. Diabetologia 27 : $421-426$

5. Yki-Järvinen $H$, and Koivisto V (1986) Natural course of insulin resistance in Type 1 diabetes. $\mathrm{N}$ Engl J Med 315: 224-230

6. Schober E, Schernthaner G, Frisch H, Fink M (1984) B-cell function recovery is not the only factor responsible for remission in Type 1 diabetics: evaluation of C-peptide secretion in diabetic children after first metabolic recompensation and at partial remission phase. J Endocrinol Invest 7: 507-512

7. Knip M, Säkkinen A, Huttunen N-P, Käär M-L, Länkele S, Mustonen A, Åkerblom H (1982) Postinitial remission in diabetic children - an analysis of 178 cases. Acta Paediatr Scand 71: 901-908

8. Knip M, Puukka R, Käär M-L, Åkerblom H (1982) Remission phase, endogenous insulin secretion and metabolic control in diabetic children. Acta Diabet Lat 19: 243-251 
9. Crossley J, James A, Elliot R, Berryman C, Edgar B (1981) Residual beta cell function and islet cell antibodies in diabetic children. Pediatr Res 15: 62-65

10. Rogers S, Silink M (1985) Residual insulin secretion in insulin dependent diabetes mellitus. Arch Dis Child 60:200-203

11. Lendrum R, Walker G, Cudworth A, Theophanides C, Pyke D, Bloom A, Gamble D (1976) Islet-cell antibodies in diabetes mellitus. Lancet II: 1273-1276

12. Lernmark $\AA$, Freedman Z, Hofman C, Rubenstein A, Steiner D, Jackson R, Winter R, Traisman H (1978) Islet-cell-surface antibodies in juvenile diabetes mellitus. N Engl J Med 299: 375-380

13. Palmer J, Asplin C, Clemons P, Lyen K, Tatpati O, Raghu P, Paquette $T$ (1983) Insulin antibodies in insulin dependent diabetes before insulin treatment. Science 222: 1337-1339

14. Marner B, Agner T, Binder C, Lernmark $\AA$, Nerup J, Mandrup Poulsen T, Walldorff $S$ (1985) Increased reduction in fasting Cpeptide is associated with islet cell antibodies in Type 1 (insulindependent) diabetes mellitus. Diabetologia 28: 875-880

15. Ludvigsson J (1984) Insulin antibodies in diabetic children treated with monocomponent porcine insulin from the onset: relationship to B-cell function and partial remission. Diabetologia 26: $138-141$

16. Arslanian S, Becker D, Rabin B, Atchison R, Eberhardt M, Cavender D, Dorman J, Drash A (1985) Correlates of insulin antibodies in newly diagnosed children with insulin-dependent diabetes before insulin therapy. Diabetes 34: 926-930

17. Karjalainen J, Knip M, Mustonen A, Ilonen J, Åkerblom $\mathrm{H}$ (1986) Relation between insulin antibody and complement-fixing islet cell antibody at clinical diagnosis of IDDM. Diabetes 35: 620-622

18. Wallensteen M, Persson B, Dahlquist G (1987) The urinary Cpeptide excretion in normal healthy children. Acta Peadiatr Scand 76: $82-86$

19. Heding L (1975) Radioimmunological determination of human C-peptide in serum. Diabetologia 11: 1-8

20. Jeppsson J-O, Franzen B, Gaal A (1980) Simplified determination of hemoglobin $A_{1} \mathrm{c}$ in diabetic patients by use of electrofocusing. In: Rodala BJ (ed) Electrophoresis: advanced methods in biochemical and clinical applications. Walter de Gruyter, Berlin, p 655

21. Persson B (1970) Determination of plasma acetoacetate and Dbeta-hydroxybutyrate in newborn infants by an enzymatic fluorometric micromethod. Scand J Clin Invest 25: 9-18

22. Landin-Olsson M, Sundkvist G, Lernmark $\AA$ (1987) Prolonged incubation in the two-colour immunofluorescence test increases the prevalence and titres of islet cell antibodies in Type 1 (insulin-dependent) diabetes mellitus. Diabetologia 30:327-332

23. Bonifacio E, Lernmark $\AA$, Dawkins LR et al. (1988) Serum exchange and use of dilutions have improved precision of measurement of islet cell antibodies. J Immunol Methods 106: 83-88
24. Christiansen A (1973) Radioimmunoelectrophoresis in the determination of Insulin binding to IgG. Methodological studies. Horm Metab Res 5: 147-154

25. Sochett E, Daneman D, Clarson C and Ehrlich R (1987) Factors affecting and patterns of residual insulin secretion during the first year of Type 1 (insulin-dependent) diabetes mellitus in children. Diabetologia 30: 453-459

26. Knip M, Akerblom H (1983) Plasma C-peptide and insulin in neonates, infants and children. J Pediatr 99: 103-105

27. Amiel S, Sherwin R, Simonson D, Lauritano A, Tamborlane W (1986) Impaired insulin action in puberty, a contributing factor to poor glycemic control in adolescents with diabetes. $\mathrm{N}$ Engl $\mathrm{J}$ Med 315: 215-219

28. Lindgren F, Dahlqvist G, Efendic S, Möller E, Persson B, Thalme B, Landin-Olsson M (1987) Glucose induced insulin response and insulin sensitivity is not related to HLA-type but to age in young siblings of Type 1 (insulin-dependent) diabetic patients. Diabetologia 30: 727-732

29. The DCCT Research Group (1987) Effects of age, duration and treatment of insulin dependent diabetes mellitus on residual $\beta$ cell function: observations during eligibility testing for the diabetes control and complications trial (DCCT). J Clin Endocrinol Metab 65: 30-36

30. Betterle C, Presotto F, Pedini B, Moro L, Slack R, Zanette F, Zanchetta $R$ (1987) Islet cell and insulin autoantibodies in organspecific autoimmune patients. Their behaviour and predictive value for the development of Type 1 (insulin-dependent) diabetes mellitus. A 10-year follow-up study. Diabetologia 30: 292-297

31. Unger R, Grundy S (1985) Hyperglycaemia as an inducer as well as a consequence of impaired islet cell function and insulin resistance: implications for the management of diabetes. Diabetologia 28: 119-121

32. Henriksen J, Tronier B, Bulow J (1987) Kinetics of circulating endogenous insulin, C-peptide and proinsulin in fasting nondiabetic man. Metabolism 36: 463-468

33. Mogensen C, Andersen M (1975) Increased kidney size and glomerular filtration rate in untreated juvenile diabetes: Normalization by insulin-treatment. Diabetologia 11: 221-224

Received: 4 March 1988

and in revised form: 22 June 1988

Dr. M. Wallensteen

Karolinska Institute

Department of Pediatrics

St.Göran's Children's Hospital

S-112 81 Stockholm

Sweden 